\title{
Plant-parasitic nematodes of strawberry in Egypt: a review
}

\author{
Mahfouz M. M. Abd-Elgawad
}

\begin{abstract}
Egypt is experiencing a revival of the strawberry cultivation backed by its Mediterranean climate, fertile soils, and geographic location which support high production and profitability of such a specialty crop. These factors can collectively offer early fruiting and long harvest season, good quality, low production costs, and closeness of export markets. However, plantparasitic nematodes (PPNs) rank high among pests and diseases that can cause considerable yield losses in the crop size and quality. The nematode losses vary according to nematode species, population density, and biotic and abiotic factors. Interaction of nematodes with soil-borne fungi increases the severity of disease, and their synergistic effect may result in much higher losses. Therefore, important PPNs on strawberry in Egypt and issues relevant to strawberry yield losses are presented herein. Meloidogyne spp. are the most predominant species on strawberry plants in Egypt. Integration of different methods such as cultural, chemical use of resistant cultivars and naturally occurring biological control agents suggested herein can play a significant role in sustainable nematode pest management of strawberry. For nurseries, there is an urgent need to motivate private and governmental sectors to satisfy the requirement of our national certified strawberry seedlings.
\end{abstract}

Keywords: Nematode management, Sampling, Strawberry, Yield loss

\section{Introduction}

Strawberry (Fragaria $\times$ ananassa Duchesne) is a widely grown hybrid species of the genus Fragaria, collectively known as the strawberries. It is cultivated worldwide mainly for its fruit but has other beneficial uses (Anonymous 2018a). Admittedly, its cultivated area in Egypt has been increasing in recent years especially due to the Mediterranean climate, fertile soils, and geographic location which support high production and profitability of such a specialty crop. These factors can collectively offer early fruiting and long harvest season, good quality, low production costs, and closeness of export markets. Egypt occupies the fourth largest producer of strawberries in the world (Essa 2015). Clearly, with the ongoing nature of the economic crisis and dramatic free float of the Egyptian pound, the socio-economic importance of strawberry is enhanced because, in addition to local consumption of strawberry as a fresh fruit and juice, commercial strawberry production provides a significant source of foreign currency in Egypt. Also, it alleviates the problem of unemployment (El-Shemy et al. 2013).

Correspondence: mahfouzian2000@yahoo.com

Plant Pathology Department, National Research Centre, Dokki, Giza 12622, Egypt
However, many strawberry varieties are quite susceptible to many types of pathogens, parasites, and pests (e.g., Kuhar and Pfeiffer 2000; El-Shemy et al. 2013; Essa 2015; Joseph et al. 2017). Plant-parasitic nematodes (PPNs) rank high among them in Egypt (Abdet-Sattar et al. 2008; El-Habashy 2010) and elsewhere (e.g., Samaliev and Mohamedova 2011; Noling 2016). Abd-Elgawad (2014) estimated annual yield losses of strawberry due to damage by plant-parasitic nematodes in Egypt as $12 \%$. This accounted for actual annual yield loss of 33,040.5 metric tons in 2012. Also, soil-borne pathogens were generally documented to interact with nematodes aggravating the yield losses (e.g., LaMondia 1999; LaMondia and Cowles 2005a). Results of the survey study in the three main Egyptian governorates for growing strawberry i.e., El-Beheira, El-Ismailia, and El-Qaluobia, revealed the presence of 10 genera of PPNs in strawberry soil and root samples (El-Habashy 2010). The root-knot nematodes (RKNs) Meloidogyne spp. were the most prevalent. The nematode genera Aphelenchus, Hoplolaimus, Ditylenchus, and Tylenchus showed 6.69, 9.38, 16.53 , and $26.32 \%$ frequency of occurrence (FO), respectively. While, FO for the genera Tylenchorhynchus, Trichodorus, Pratylenchus, Aphelenchoides, and
Springer Open

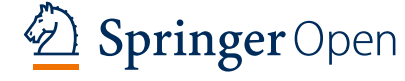

(c) The Author(s). 2019 Open Access This article is distributed under the terms of the Creative Commons Attribution 4.0 International License (http://creativecommons.org/licenses/by/4.0/), which permits unrestricted use, distribution, and reproduction in any medium, provided you give appropriate credit to the original author(s) and the source, provide a link to the Creative Commons license, and indicate if changes were made. 
Xiphinema were $3.59,4.45,4.46,5.35$, and $2.22 \%$, respectively. Also, based on field observations, species of Meloidogyne, Pratylenchus, and Aphelenchoides are currently the most economically important and prevalent PPN pests in Egyptian strawberry fields. Moreover, in the context of strawberry seedling importation from foreign countries, invasive nematodes such as Trichodorus species (stubby-root nematodes) have been detected in limited strawberry farms. Therefore, nematode quarantine programs and continuous reassessment of PPN fauna in Egypt should be upgraded. In this concern, Salama and Abd-Elgawad (2003) discussed such quarantine problems for PPNs and presented an analytical approach to address them.

Yields of strawberry typically decrease over time after maximum growth, but feeding by nematodes accelerates decline by such above-mentioned concomitant PPN species especially at high population densities and favoring biotic and abiotic factors. Admittedly, nematode problems may be aggravated in many Egyptian fields due to lack of farmer knowledge on proper measures for control of PPNs. This review presents background information scope on PPNs in Egyptian strawberry fields, focusing on the most common and damaging nematodes. Due to their different densities and species in various Egyptian governorates, PPNs were grouped in a descending order according to the economic importance. The article throws light on their significance and provides a way forward for control tactics of their important PPN genera as well as general management strategies to maximize strawberry yield and quality in Egypt. An improved approach for sample size optimization is presented since PPN sampling accuracy and precision are basic to nematode research and rational management decision.

\section{PPNs of strawberry in Egypt Root-knot nematodes (Meloidogyne spp.)}

RKNs are obligate parasites of the plant roots. They have wide host range including monocotyledonous and dicotyledonous, herbaceous, and woody plants. The genus includes more than 90 species, with some species having several races. Four Meloidogyne species (M. javanica, $M$. arenaria, $M$. incognita, and $M$. hapla) are major pests worldwide, with other seven being important on a local basis (Eisenback and Triantaphyllou 1991; Moens et al. 2009). Root-knot nematodes have very high reproductive potentials as single females can produce up to 500 eggs. In Egypt, RKNs constitute a major constraint to agricultural production, especially in sandy soil and reclaimed desert lands. Ibrahim et al. (2010) reported that Meloidogyne spp. were the most frequently encountered PPN genus associated with many host plants in Egypt; with $62.5 \%$ frequency of occurrence. Percentage of occurrence of Meloidogyne spp. was $96.26 \%$ in surveyed fields of newly reclaimed lands (Bakr et al. 2011) which are likely to be planted with horticultural crops such as strawberry. The survey included El-Beheira (El-Tahrir), Minufiya (El-Sadat), and Sharkiya (El-Salhiya) governorates which represent different categories of light soils. Also, RKNs were more predominant in samples collected from Sahl El-Teina, Beer El-Abd, and El-Sheikh Zowaiid with the percentage frequency of $27.6,48.1$, and $33.3 \%$, respectively (Korayem et al. 2014).

In the three main Egyptian governorates famous for cultivation and export of strawberries, RKNs recorded an average of $35.6 \% \mathrm{FO}, 4203.5$ prominence value, and 704.5 RKN juveniles per $\mathrm{kg}$ strawberry-planted soil (El-Habashy 2010). Nevertheless, the magnitude of RKN population levels may vary greatly from one field to another based on agricultural practices, edaphic factors, and nematode control tactics and strategies. In each of these three governorates, Meloidogyne spp., as the most damaging nematodes in Egypt (Abd-Elgawad 2014), showed 41.3\% FO in samples of strawberry-planted soil in El-Ismailia, $30 \%$ in El-Qaluobia, and $35.5 \%$ in El-Beheira governorate (El-Habashy 2010). Cultivating strawberry on rice straw bales proved to keep the fruits and roots away from contacting the soil and thus limits the possibility of infection by soil-borne fungi and PPNs. The occurrence of damping-off, root rot, crown rot and root-knot nematodes in strawberry plants grown on rice straw bales recorded $4.0,0.85,0.35$, and $0.0 \%$, respectively (Abdet-Sattar et al. 2008). Their corresponding figures for strawberry plants grown in natural soil under the same conditions were $27.0,16.15,11.70$, and $13.20 \%$, respectively, 135 days after planting.

Since PPNs generally have aggregated or patchy distribution in Egypt (e.g., Abd-Elgawad 1992; Abd-Elgawad and Hasabo 1995) and elsewhere (Duncan and Phillips 2009; Abd-Elgawad and Askary 2015), symptoms of RKN infection tend to occur in more or less definite areas where transplants fail to develop normally (Fig. 1). Infested patchy areas are usually fairly well defined from those with healthy plants. Unless a proper nematode control measure is followed, a field infested with RKNs, or the like nematode pests, which has only a few such patchy areas at the beginning of the growing season may then increase in size and number until almost the whole field will be infested. As with other PPNs, the general impact of RKNs on strawberries is to cause both stunting and decline in plant growth and subsequent yield, the intensity of which is related to initial nematode population level and the rate to which population increase in reaction to the infested plants during the growing season. Plantings which are stunted by nematodes often have worse weed problems than areas without nematode injury because the crop is less able to compete 


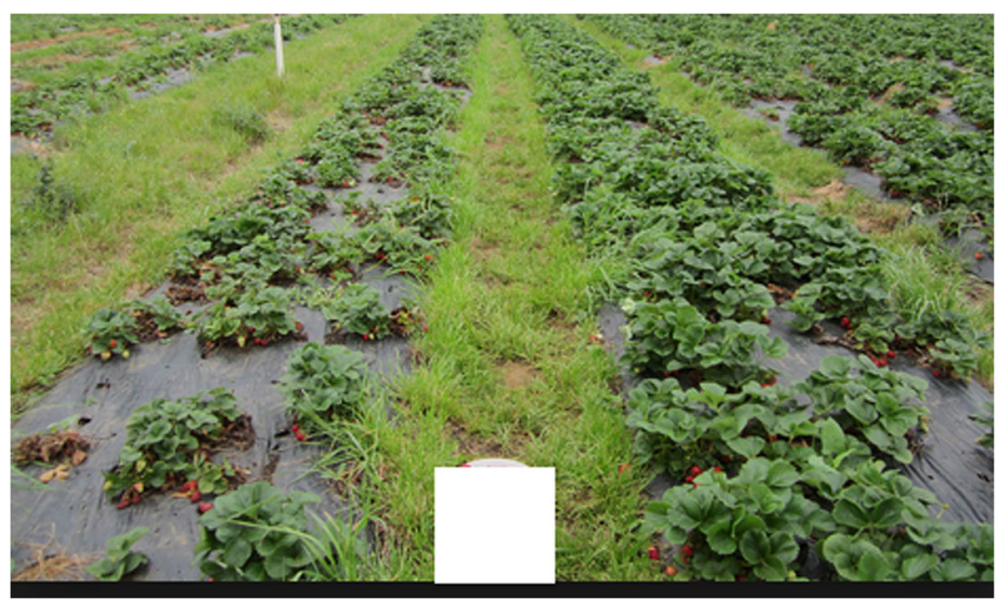

Fig. 1 A strawberry field showing patchy area due to root-knot nematode infestation

with weeds or even any other stresses than it should be. Most symptoms associated with them are the result of inadequate water supply or mineral nutrition to the tops. Unlike most plant-parasitic nematodes, feeding by RKNs induces distinguished knot-like swellings (called galls) on the roots. When plants are severely infected by Meloidogyne, the normal root system is reduced to a limited number of severely RKN-galled roots with a completely disorganized vascular system. The RKN-infected roots are seriously hampered in their main functions of uptake and transport of water and nutrients. Consequently, the plants do not flower properly and therefore produce fruits of poor quality, and it is very easy to get drought damage. Rootlets are almost completely absent at severe infestation which may render plant death. Presence of strawberry white grub, Temnorhynchus baal Reiche and Saulcy, may extend plant damage by eating subterranean roots. If so, most of the remained hairy roots turn blackish.

In addition, nematode infection wounds the roots and this makes the plants vulnerable to attack by other pathogens such as bacteria and root-rot fungi. Similar to Belonolaimus longicaudatus-infected strawberry (Noling 2016), leaf edges of Meloidogyne spp.-infected strawberry turn brown, progressing or expanding from the edges to midrib to include the entire leaf. Since the outer, older leaves die first, the plant gradually decreases in size and eventually may be killed. Yet, RKN symptoms are uniquely characterized on plant roots (Fig. 2).

The three RKN species of most common occurrence and spread in Egypt in a descending order are M. incognita, M. javanica, and M. arenaria (Ibrahim 1985). El-Habashy (2010) illustrated roots infected by each of these species for different strawberry cultivars commonly grown in Egypt. Reaction of four strawberry cultivars-namely, K14, Chandler, Festival, and Sweet
Charli-to the three separate species revealed their susceptibility though to different degrees. The cultivar Festival was highly susceptible while K14 was less susceptible against the tested species (El-Habashy 2010). $M$. hapla is also found, but of limited occurrence, especially in relatively cold northern coastal region of Egypt (Ibrahim et al. 2010) where strawberry is not usually grown.

The threshold level of RKNs is so low that any nematode detection (one RKN/sample) may necessitate control measures in areas allocated for strawberry plantations (Abd-Elgawad and Askary 2015). Nematode control, especially RKNs, should be a pre-consideration. For example, Oteifa and Elgindi (1983) tested the RKN-host suitability of 79 cultivars of 21 economic crops. They found that some cultivars were immune or resistant to some biotypes of $M$. incognita and $M$. javanica. Exploiting such information for proficient utilization of the resistant/immune cultivars, which have compatible rotation with strawberry, may enhance RKN control strategy in Egypt. The North Carolina differential host test revealed the occurrence of $M$. incognita races 1 and 3 and $M$. arenaria race 1 only in Egypt (Ibrahim 1985) while few strawberry plants seemed as non-hosts for Egyptian RKNs (MMA Youssef, Pers. Comm., NRC). Each oxamyl (Vydate 10G) and the biological nematicides Nemacont and Bionema caused significant reduction in numbers of RKN galls, egg masses, and number of larvae/250 g soil planted to strawberry compared with untreated control (El-Habashy 2010). This author reported also that commercial nematicides Rugby, Furadan, Vydate, Nemacont, and Bionema improved root and shoot growth of strawberry cv. Festival infected with $M$. incognita. He tested four different plant oils: black cumin, argel, fennel, and garlic at concentrations $125,250,500$, and $1000 \mu \mathrm{l} / \mathrm{l}$ on $M$. incognita eggs 


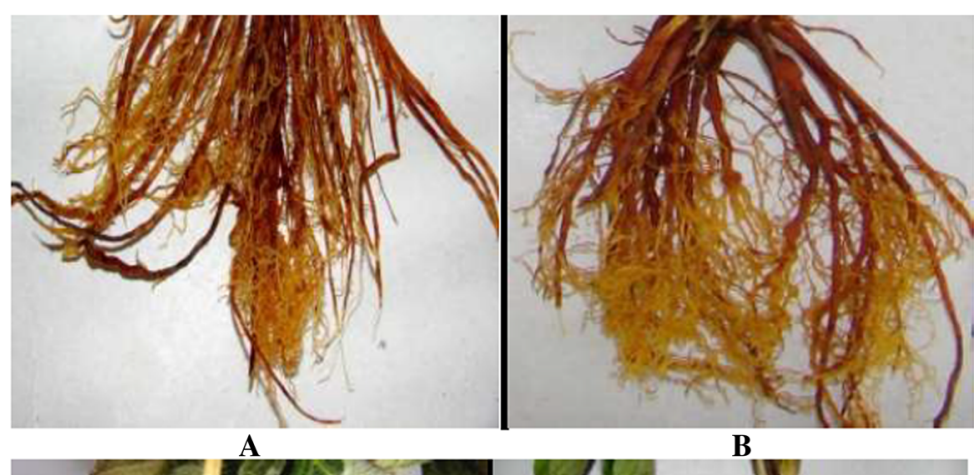

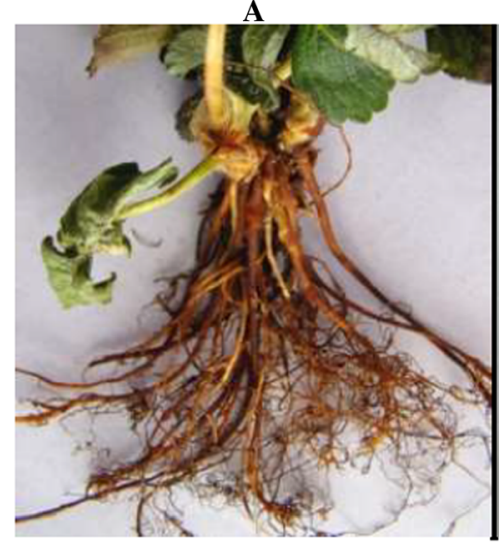

C

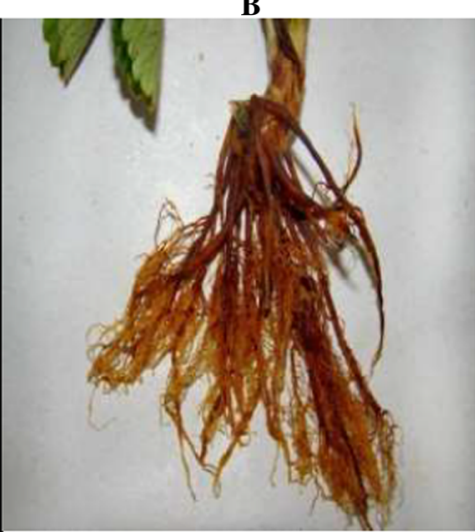

D

Fig. 2 Nematode galls on roots of four strawberny cultivars infected with Meloidogyne incognita. a K14. b Chandler. c Festival. d Sweet Charli (El-Habashy 2010)

hatching percentage after 3,5 , and 7 days from treatment. All the tested plant oils significantly reduced eggs hatching percentage. The more concentrations tested, or time elapsed, the better it suppresses eggs hatching. Generally, the oil of garlic was the best to reduce $M$. incognita eggs hatching followed in a descending order by argel, black cumin, and fennel. Also, these plant oils induced significant increase in the mortality percentage of $M$. incognita second-stage juveniles $\left(\mathrm{J}_{2}\right)$ after 12,24 , and $48 \mathrm{~h}$, respectively compared with the untreated control. Similar trends of their effects on eggs hatching were also noticed on $M$. incognita- $\mathrm{J}_{2}$; the best results were obtained at exposure to maximum concentration and duration. Eventually, the tested concentrations of garlic oil caused significant decrease in the number of nematode-root galls, egg masses, and $\mathrm{J}_{2}$ number $/ 250 \mathrm{~g}$ soil simultaneously with improved root and shoot growth of strawberry cv. Festival compared to the untreated control (El-Habashy 2010).

Identifying appropriate conditions for nematode infection and development is an important key for nematode control and their consequent loss reduction. For example, in temperate/warm, sandy soils attack by the three common RKN species promotes severe stunting to strawberry plants generally. Control measures are usually enough to prevent seedling death or significant damage by PPNs in Egyptian nurseries which usually apply sanitary measures and/or chemical nematicides. Death is more likely to occur if other plant pathogens/ stressed conditions are involved in the field. Problems are most severe during periods of drought because RKN-infested strawberry plants often seem starved for water. Cultivars with polygenic resistance to M. hapla have been bred in Europe, and varieties differ in their tolerances to the nematode (Warner 2018). Also, biochemical studies on isolation and characterization of RKN-resistant genes to produce transgenic strawberry plants by molecular bio-techniques were done in Egypt (Salem 2016). Results showed that the predicted open reading frame (ORF) had $99 \%$ identity to the published $C r y I A a$ and $C r y I A b$ nematode resistance gene. To verify the expression Cry1 $A a$ and $C r y 1 A b$, these genes were constructed into pET 29a plasmid under the control of a T7 promoter then transformed into Escherichia coli BL21 bacteria. Results of protein analysis indicated that the Cry1 Aa and Cry1 Ab genes were expressed as $65 \mathrm{KD}$. Regeneration system has been established for transformation of the susceptible strawberry cultivar Diamante on Murashige and Skoog medium. This medium was supplemented with different combinations of growth regulators such as naphthaleneacetic acid, indole-3-acetic acid, and zeatin and thidiazuron (Salem 
2016). She also screened putative transformation regenerated from explants on regeneration medium with antibiotics using Beta-glucuronidase (Gus) assay and confirmed by PCR. Gus expression was observed in transformed strawberry shoots but never in non-transformed (untreated) check. Gus-positive explants reacted positively to PCR, and the obtained results indicated that the $M$. incognita resistance genes of interest CryI $A a$ and $C r y I A b$ were introduced in strawberry genome. However, such information on resistance to M. hapla in Europe (Warner 2018) and transgenic strawberry plants resistant to $M$. incognita in Egypt (Salem 2016) is not always readily available. Even when conducted by public institutions, advances in resistant and/or sober varieties have generally tended to be proprietary.

\section{Lesion nematodes (Pratylenchus spp.)}

The genus Pratylenchus has a wide host range feeding on almost every species of cultivated plants. Many weeds also serve as good hosts. Numerous species of Pratylenchus are known to be associated with crops, grasses, and weeds in Egyptian soils. Consequently, it is quite possible to plant strawberries in such soils reported by Ibrahim et al. (2010) infested with one or more of the following species: $P$. coffeae, $P$. brachyurus, $P$. crenatus, $P$. goodeyi, $P$. minyus, $P$. musicola, $P$. neglectus, $P$. penetrans, $P$. pratensis, $P$. scribneri, $P$. thornei, $P$. vulnus, and $P$. zeae. In Egypt, information is scanty on the exact strawberry yield loss caused by a definite nematode species. Yet, in addition to their role as pathogens, some species of Pratylenchus can also predispose plants to invasion by some genera of soil fungi including Cylindrocarpon, Fusarium, Pythium, Rhizoctonia, and Verticillium (Warner 2018). For example, lesion nematodes, principally $P$. penetrans, are implicated in the black root rot disease complex of strawberry in Connecticut, USA. It was demonstrated that lesion nematodes and Rhizoctonia fragariae interacted to more than double the development of strawberry black root rot under controlled conditions. The interaction of $P$. penetrans, black root rot disease caused by $R$. fragariae, and strawberry root damage caused by feeding of the scarab larva, Maladera castanea, was determined in greenhouse studies (LaMondia and Cowles 2005a). Averaged over all experiments after 12 weeks, root weight was reduced $13 \%$ by $R$. fragariae and $20 \%$ by $M$. castanea. The percentage of the root system affected by root rot was increased by inoculation with either R. fragariae (35\% more disease) or $P$. penetrans (50\% more disease) but was unaffected by M. castanea. The percentage of $R$. fragariae-infected root segments was increased 3.6-fold by inoculation with $R$. fragariae on rye seeds. The presence of $P$. penetrans also increased $R$. fragariae root infection.
Eventually, the lesion nematode, $P$. penetrans, increased $R$. fragariae infection and the severity of black root rot (LaMondia and Cowles 2005a).

Damage by $P$. penetrans is greatest on light soils where a damage threshold of 50 nematodes $/ 100 \mathrm{~g}$ of soil has been reported (LaMondia 1999). The threshold is probably as low as 10 nematodes $/ 100 \mathrm{~cm}^{3}$ if $R$. fragariae is also present. Pratylenchus penetrans alone or in combination with the black root rot pathogen, $R$. fragariae, reduced strawberry produce in microplots over time (LaMondia 1999). In field infested with $P$. penetrans alone, plant vigor and yield were enhanced by applying carbofuran and fenamiphos nematicides. Nematode control was relatively short term, as $P$. penetrans populations were initially suppressed but were not different in samples taken 10 months after treatment. Therefore, LaMondia (1999) highlighted the error in associating causality between plant damage and nematode populations based on a correlation of root disease with nematode diagnostic assays from severely diseased plants. Clearly, such data may help to explain how nematode numbers can sometimes be higher in healthy plants than in severely diseased plants that lack sufficient roots to maintain nematode populations. On the other hand, the regression between lesion nematode populations and strawberry yield was used to predict fruit yield losses from fruiting year two to four (LaMondia 1999). Strawberry fruit weight was best correlated with nematode densities 1 year before harvest. The resulting percent reduction in profits was calculated using an economic model (DeMarree and Rieckenberg 1998) with fruit yield as an input. Initial densities of 50 nematodes/g root reduced yield by $10.3 \%$ and reduced accumulated profit by $32.4 \%$ over the four fruiting years. The accumulated fixed and variable costs of producing the crop over that time increase the loss in profit to beyond the percentage of annual fruit yield loss due to the pest alone. Initial lesion nematode densities of 100, 150, and 200/g root reduced yield by $20.5 \%, 30.8 \%$, and $41.0 \%$ respectively but reduced accumulated profit by $63.7 \%, 95.3 \%$, and > $100 \%$, respectively. The decline in yield experienced in these scenarios and resulting economic losses would likely result in the early removal and replanting of the crop (LaMondia 1999).

Generally, lesion nematodes are difficult to control and therefore various management measures should be used in integrated pest management (IPM) approach. This approach will be addressed below in the paper for various PPN genera. Specifically, rotating pearl millet with susceptible crops such as strawberry has been used successfully in Egypt (pers. comm., Hosam Elmiligee, All Green Co., El-Behera, Egypt) against PPNs and in Michigan, USA (Warner 2018) to reduce population densities of $P$. penetrans. A basic control strategy is to use nursery 
stock free from PPNs especially RKNs and lesion nematodes. Assuming most strawberry sites are infested with $R$. fragariae, decline of a new planting will be faster if the new plants are infested with nematodes. Strawberry varieties differ in their susceptibilities to $R$. fragariae; e.g., Jewel is tolerant to $R$. fragariae. So, it is wise to exploit the degree of host suitability in the nematode control programs. Also, soil fumigation can effectively control black root rot. In addition, weed control is imperative to alleviate nematode damage (Warner 2018). Limitations in expanding nematode control efforts are further aggravated by the lack of awareness of efficient implementation methods by resource-poor Egyptian farmers as well as their limited knowledge of plant clinics where farmers can obtain diagnosis and plant health advice. In USA, LaMondia and Cowles (2005b) concluded that lesion nematode impact on the strawberry crop was likely much larger than perceived by growers.

\section{Leaf and bud (or foliar) nematodes (Aphelenchoides spp.)}

The nematodes have a wide host range of growing plants which mostly include ferns, many weeds, and members in plant families Liliaceae, Primulaceae, Ranunculaceae, and Compositae (Sturhan 1962). Yet, to the best of my knowledge, these nematodes were not uncovered so far from strawberry plants in Egypt though found in Egyptian fauna associated with other plants such as groundnut pods (Montasser et al. 2008) and causing white tip leaf disease on rice (Amin 2001). I suppose it is also associated with strawberry plants in Egypt but has not been detected yet. Three common species of these nematodes are Aphelenchoides besseyi, A. fragariae, and $A$. ritzemabosi. The first species is recognized mainly for causing the white tip disease of rice in Egypt and elsewhere (Youssef 2014) while A. fragariae and A. ritzemabosi are responsible for strawberry crimp disease known also as spring dwarf, spring crimp, or red plant (CABI 2018). Unlike most PPN species which invade roots, these are foliar pests. They have short life cycles (egg to adult in 14days) and high reproductive potentials, so they can increase in number very rapidly (Warner 2018).

On strawberry, A. fragariae causes malformations of the shoot such as twisting and puckering of leaves, discolored areas with a hard and rough surface, undersized leaves with crinkled edges, reddening of petioles, short internodes of runners, reduced flower trusses with only one or two flowers, and death of the crown bud (CABI 2018). Ectoparasitic feeding on folded crown and runner buds causes small dry, brown feeding areas which can be seen on expanded leaves usually near the midrib; occasionally, the nematodes are found in strawberry fruit pulp (Tacconi 1972). Endoparasitic feeding within leaf tissue produces typical leaf-blotch symptoms. The strawberry disease may be due wholly or partly to A. fragariae; sometimes, these symptoms could be due to other nematodes (A. ritzemabosi or Ditylenchus dipsaci) or caused by bacteria or frost (CABI 2018). These nematodes cause also distortion of the strawberry leaves. Damage by these nematodes is most noticeable on newly formed leaves soon after; growth is initiated in the spring (spring dwarf). However, symptoms may also become evident in the fall. Veins often act as barriers to foliar nematode movement, so symptoms are often interveinal appearing as grayish spots that may turn brown. Leaves are often distorted. Eventually, foliar nematodes are potentially destructive pathogens of strawberry. Experiments in Germany demonstrated Aphelenchoides sp. could reduce yields up to 65\% (Warner 2018).

Aphelenchoides spp. control includes removal and destruction of infected strawberry leaves. Avoiding periods of relatively long plant wetness should be considered since this nematode relies on moisture to move up the plant and between plants. Following this line of thinking, drip irrigation is preferable over overhead spray irrigation. These nematodes are vulnerable to elevated temperatures; hot water treatment at a temperature of $115^{\circ}$ F for 5 min of dormant plant materials such as strawberry runners or cuttings intended for propagation can be used and is effective at eliminating most nematodes that may be infesting the plant material (Qiu et al. 1994). Sanitation of equipment is also important to control the nematode. Pots, soil, and tools should be cleaned by baking or steaming at $180-200^{\circ} \mathrm{F}$ for $30 \mathrm{~min}$ (Anonymous 2018b). Care must be taken so that the temperatures needed to eliminate the infesting nematodes do not irrevocably harm the plant material (Jenkins and Taylor 1967).

\section{Other plant-parasitic nematodes}

In addition to the above-mentioned nematode genera and species, there are still some reported ones of apparently less economic importance in Egypt. These include, in a descending order of importance, the nematode genera Hoplolaimus, Ditylenchus, Aphelenchus, Tylenchorhynchus, Trichodorus, Xiphinema, and Tylenchus. They are often found in strawberry fields in Egypt in low population densities and frequency of occurrence. Ibrahim (2006) reported also the following PPN species associated with strawberry plants: Criconemella curvatum, C. cylindricum, Trichodorus christiei, T. cylindricus, T. pachydermus, T. similes, Tylenchorhynchus capitatus, $T$. claytoni, T. martini, Xiphinema americanum, X. chambersi, $X$. coxi, and $X$. diversicaudatum. This does not negate the fact that future studies on one or more of these species/genera may upgrade its/their economic importance and define their exact impact on strawberry 
plants in Egypt. On the other hand, the importance of other species/genera has been documented elsewhere. For example, PPNs are very important economic pests in Florida strawberry, estimated to occur on as much as $40 \%$ of Florida strawberry acreage. Nevertheless, the most important nematode pest to commercial strawberry production in Florida, USA, is the sting nematode, Belonolaimus longicaudatus (Noling 2016). Also, the needle nematodes (Longidorus spp.) are very destructive pathogens of strawberry in Michigan, USA. Longidorus spp.-infected plants are severely stunted, and roots may exhibit small swellings near their tips. A population density of 180 L. elongatus $/ 200 \mathrm{~g}$ soil was documented to reduce yield of strawberry by $50 \%$ in England as well (Warner 2018).

\section{Management of PPNs on strawberry in Egypt Common considerations Adequate nematode sampling}

Nematode sampling should be a pre-consideration. Adequate PPN sampling method, time, and process (e.g., Been and Schomaker 2013; Van den Berg et al. 2014; Abd-Elgawad 2016a) are necessary to detect and diagnose nematode problems, if any, via proper collection of relevant soil and plant tissue (roots and leaves). These samples must be sent to a nematode lab., such as Diagnostic Services at the Special Unit of the National Research Centre, Dokki, Giza governorate for analyses prior to strawberry transplanting. The level of nematode numbers and their species/genera identified in these samples at pre-planting of nursery and field determines if nematode treatment is required.

Nematode threshold numbers or at least the common significance of the detected PPNs which may vary from one species/genus to another should be considered. Such a variation may be influenced by relevant biotic and abiotic factors. For example, in New Brunswick, Canada, 500 lesion nematodes per kilogram of dry soil are considered a level where pre-plant treatment to control the nematodes would be beneficial (Anonymous 2018c). Whereas, the treatment levels there for pin (Paratylenchus projectus), root knot, and needle (Longidorus spp.) nematodes per kilogram of dry soil are 5000, 500, and 200 respectively. Yet, treatment for needle nematodes is usually only considered when they are found in combination with dagger nematodes (Xiphinema spp.) in the same field. Spiral (Helicotylenchus spp.), stunt (Tylenchorynchus spp.), and ring (Criconemoides spp.) nematodes are frequently found in samples from strawberry plantations. However, like Egypt, their exact impact on yield, if any, is not recorded. Moreover, damage threshold level for species of root-knot, sting (Belonolaimus), lesion, and sheath (Hemicycliophora) nematodes associated with strawberry plants is given by nematode extension service, University of Florida, USA. Minimum numbers of these nematode genera per $100 \mathrm{~cm}^{3}$ of soil at which the crop is at risk of nematode damage are 1,1 , 80, and 80, respectively (Abd-Elgawad and Askary 2015). Such pre-plant thresholds may not be useful on established strawberry. Action thresholds necessitate RKN control if it is detected from strawberry-planted soil in Egypt too. Generally, nematode population levels may affect strawberry yields differently under various conditions.

Sampling accuracy, which usually increase with more number of samples, is basic to nematode advisory and diagnostic services. However, sampling intensity is dictated by the time, effort, and money stakeholders are ready to invest rather than by what is required to achieve a specified level of accuracy. Admittedly, the more the accuracy and/or precision level is, the higher the sampling cost becomes and vice versa. Nevertheless, with the recent advances in nematode sampling, extraction processes, and counting (e.g., Been and Schomaker 2013; Reid et al. 2015; Holladay et al. 2016), new avenues are opened for further options to optimize the above-mentioned costs. Therefore, contrary to previously reported sampling reliability levels, a precision level of not less than $90 \%$ is adopted herein (Table 1). Yet, if such a reliability level were a cause for concern, it could be reduced by collecting, extracting, and counting more samples per plot. Higher precision than the commonly used one may be adopted especially when the management threshold figure for each of the above-mentioned nematodes lies within the confidence interval of the sample mean for the studied species. Recent developments in sample collection, processing, and counting may facilitate such an adoption. On the contrary, if nematode population means, and consequently their confidence band, are well above or below economic threshold levels, there is no need to adopt a high precision level. Furthermore, Abd-Elgawad (2016a) could improve optimum sample size of nematode samples via iteration. Hence, such a technique is applied herein (Table 1) to derive improved sample size for Pratylenchus spp. and M. incognita. For example, improved estimates of sample size needed to achieve a $10 \%$ level of reliability for M. incognita were 480 and 375 instead of 498 and 388 samples, respectively (Table 1). Moreover, Abd-Elgawad (2016a) suggested that better practicality of sampling cost and benefit trade-off is gained when different levels of sampling reliabilities along with their corresponding costs are given.

\section{The need to back nematode quarantine and certification programs}

For nurseries, there is an urgent need to motivate private and governmental sectors to satisfy the requirement of 
Table 1 Iteration-based improvement in minimum number of nematode samples needed to achieve a 10\% level of reliability as defined in terms of standard error to mean ratio $(E)$ or confidence interval half-width to mean ratio $(D)$ with iteration*

\begin{tabular}{|c|c|c|c|c|}
\hline $\begin{array}{l}\text { Mean count per } \\
\text { sample }^{+}\end{array}$ & $\begin{array}{l}\text { Number of samples } \\
\text { via }(E)\end{array}$ & $\begin{array}{l}\text { Student's } t \\
\text { value }\end{array}$ & $\begin{array}{l}\text { Number of samples } \\
\text { via }(D)^{++}\end{array}$ & Improvement in sample size \\
\hline \multicolumn{5}{|c|}{ Pratylenchus spp.: The power law parameters $a=1.58, b=1.33$} \\
\hline \multirow[t]{3}{*}{1} & \multirow[t]{3}{*}{158} & 2 (assumed) & 632 & \multirow[t]{6}{*}{609 and 209 instead of 632 and 215 samples, respectively } \\
\hline & & $1.964(n=632)$ & 609 & \\
\hline & & $1.9638(n=609)$ & 609 & \\
\hline \multirow[t]{3}{*}{5} & \multirow[t]{3}{*}{54} & 2 (assumed) & 215 & \\
\hline & & $1.971(n=215)$ & 209 & \\
\hline & & $1.971(n=209)$ & 209 & \\
\hline \multicolumn{5}{|c|}{ Meloidogyne incognita: The power law parameters $a=2.92, b=1.47$} \\
\hline \multirow[t]{3}{*}{5} & \multirow[t]{3}{*}{124} & 2 (assumed) & 498 & \multirow[t]{3}{*}{480 and 375 instead of 498 and 388 samples, respectively } \\
\hline & & $1.966(n=498)$ & 480 & \\
\hline & & $1.965(n=480)$ & 480 & \\
\hline \multirow[t]{3}{*}{8} & \multirow[t]{3}{*}{97} & 2 (assumed) & 388 & \\
\hline & & $1.966(n=388)$ & 375 & \\
\hline & & $1.966(n=375)$ & 375 & \\
\hline
\end{tabular}

*The $t$ value is either assumed as 2 for $95 \%$ confidence interval or iterated using its tabulated value from: http://www.danielsoper.com/statcalc3/calc.aspx?id=10 ${ }^{+}$Based on a sample size of $100 \mathrm{~g}$ soil (iterated from original data reported by Abd-Elgawad et al. (2008))

${ }^{++}$The fractional values rounded up to nearest integer

our national certified strawberry seedlings. A strawberry nursery certification program against PPNs, especially RKNs, should include strict sanitation practices especially both site approval and pre-movement certification of strawberry seedlings before they leave the nurseries. Similar citrus certification program has been successful in Florida, USA (Inserra et al. 2005). Therefore, all stakeholders in Egypt should tackle the problem collectively and, in particular, allocate sufficient funds for certified seedlings and provide relevant experts who can apply similar adopted procedures. Regrettably, most farmers are forced to obtain seedlings from informal sources such as local private markets since certified seedlings are costly and not easily available. Limitation in distribution of certified seedlings is further aggravated by both their small-scale production and the lack of awareness of these nematodes by many resource-poor farmers. As suggested with citriculture (Abd-Elgawad et al. 2016), regulation on certifiable pathogens of strawberry-propagating material may also include bacteria, fungi, and other transmissible pathogens in Egypt.

\section{Nematode management methods}

The management should be based on a continuous plan taking into account all possible approaches; cultural, chemical, and agronomic practices especially in acreage dedicated to grow strawberry on the long term. Generally, weed control including hand hoeing, when necessary, integrated disease and pest management, adequate fertilization, proper irrigation to deliver the right amount of water at the right time, and periodic harvesting in a timely manner should be cared of. On the other hand, because numerous PPNs and other pathogens could be entangled in any strawberry disease complex, no single control measure is totally effective. Therefore, cultural practices should be strictly followed as preventive measures before applying chemical nematicides as a last resort. Many Egyptian growers have already put some of these practices in effect especially avoiding heavy, wet soils and improve soil drainage by tactful irrigation system and tillage as well as planting on raised beds. Also, it is essential to incorporate organic matter such as buffalo/poultry fertilizer as well as straw from a rotational grain crop before bed construction. Pre-plant fumigation of the soil is frequently helpful, but unauthorized fumigants occasionally used by some Egyptian growers such as methyl bromide (MB) should be avoided. Certified seedlings along with other technically qualified specifications of seedlings indicated by El-Shemy et al. (2013) to ensure healthy white-rooted plants must be a way forward in strawberry protection/pest management in Egypt. In this vein, frigo and fresh strawberry seedlings should not only be free of pests and pathogens but should also offer the best available quality. For instance, RKN (M. hapla) can considerably decrease strawberry growth and yield in Florida, USA and has been periodically reported on infested bare-root strawberry transplants imported from Canada (Noling 2016). Careful supplying of water and fertilizer according to the plant needs is necessary for each stage of the growing season 
especially at the prebloom, bloom, and fruiting periods. After final harvest, roots of both the previous crop and weeds should be destroyed as quickly as possible to remove nematode food sources. Admittedly, some Egyptian growers neglect crop rotation although strawberry should be rotated for at least 2 years before replanting to avoid or at least alleviate problems of pathogens and pests. Taking into account the above-mentioned practices and cautions, nematode management methods will be addressed herein in terms of their practical importance in Egypt.

\section{Chemical control}

Currently, soil treatment with soil-borne pathogen-effective methyl bromide, which can result in several fold increase in strawberry yields over that of nonchemical methods in USA (Noling 2016), is still applied by some small-scale growers in Egypt. Instead of its legal utilization against wood borer pests, $\mathrm{MB}$ is sometimes illegally, though effectively, used against nematodes, soil-borne pathogens, and insect pests in strawberry nurseries/fields. On the contrary, a significant re-direction in the types and choice of applicable pesticides is being adopted by medium and large companies in Egypt due to environmental issues obstructing the use of such hazardous chemicals. In this vein, 1,3-dichloropropene, or its commercial synonyms such as Telone II or Dorlone II, is widely applied in nurseries/fields for its high PPN control efficacy. Moreover, since chloropicrin has proved to be very effective against diseases but seldom nematodes or weeds, 1,3-dichloropropene is also formulated with chloropicrin (Telone C17 or Telone C35), making it a multi-purpose soil fumigant (Abd-Elgawad 2008). The product contains either $17 \%$ or $35 \%$ chloropicrin. Telone C35, applied in combination with a separately applied herbicide or fumigant product for weed control, has been identified as the best chemical alternative replacing $\mathrm{MB}$ for achieving effective PPN control and superior strawberry production (Noling 2016). Application rates of fumigant nematicides for strawberries are 2735 gal/acre (or 127.4-165.2 1/Feddan) for Telone II and 39$50 \mathrm{gal} /$ acre (or 184-236 1/Feddan) for Telone C35 (Feddan = $4200 \mathrm{~m}^{2}$ ). Appropriate soil preparation and conditions prior to plant fumigation, new fumigant product and applicator training certifications, personal protective equipment, buffer zones, mandatory good application practices, and other restrictions and requirements were recently highlighted (Noling 2016).

Nonfumigant nematicides generally used against PPNs in Egypt include aldicarb, oxamyl, turbufos, ethoprop, chlorfenapyr, and fenamphios. Valid as they are, such nematicides are presumably not as highly effective against root nematodes as the fumigants. For example, soaking roots of strawberry seedlings in oxamyl (Vydate 24\% SL) at the rate of 500 $\mathrm{ml}$ oxamyl/100 $\mathrm{l}$ of water for 1-2 min is practiced in Egypt. Nimitz is used in Florida, USA as pre-plant application at a rate of 3.5 to 7 pints per acre (or 2-41/Feddan), a minimum of 7 days before planting. Label instructions for all pesticides should be strictly followed. In recent years, many of such labels have considerably been changed with a clear aim to protect handlers in the field and residents and bystanders in close proximity of the field. Therefore, special attention should be paid on their application.

Since PPN management is mainly a pre-plant consideration, it is difficult to control the nematodes encountered during the growing season. Yet, when the nematode infection occurs after transplanting, the above-mentioned oxamyl solution can be added at a rate of $5 \mathrm{~cm}^{3} / 1$ of water around the plant roots. Also, although chitosan is typically used as a natural seed treatment and plant growth promoter, it could be applied as an ecologically friendly nematicide that enhances the plant ability to defend itself against PPN and fungal infections. Chitosan is one of the most abundant biodegradable materials in the world. In Egypt, chitosan is sometimes used in drip irrigation water at a rate of 2.5-31/Feddan to manage PPNs during strawberry-growing season (Hosam Elmiligee, pers. Comm., All Green Co., El-Behera, Egypt).

\section{Biological control}

Biological control agents (BCAs) have recently experienced considerable development. So, many commercial products are recommended to control PPNs in strawberry fields in Egypt. A few BCAs have been recently evaluated and compared to oxamyl and untreated check (Fig. 3). These BCAs gave encouraging results concerning both reducing nematode development parameters and increasing strawberry fruit yield (Hammam et al. 2019), including beneficial entomopathogenic nematodes (EPNs). Such EPNs, mainly Heterorhabditis bacteriophora and Steinernema feltiae, were also found in 75\% of fields to which commercially obtained EPNs had been applied and to $14 \%$ of the remaining fields (LaMondia and Cowles 2005b). The latter authors reported that the presence of naturally occurring EPNs in strawberry fields may control root weevil populations and lead to more years of strawberry productivity. However, the current practice suggests that they should not be seen as direct competitors with the above-mentioned chemical nematicides for several reasons that include cost, ease of use and storage, and speed of kill. Instead, BCAs can be included in integrated pest management programs in trends that make them able to contribute synergistically or complimentary to other chemicals or BCAs. Clearly, research programs should not be limited exclusively to evaluation of chemical combination treatment regimes.

\section{Common cultural practices in Egypt}

Intercropping is an ideal of Egyptian agriculture because it increases crop production by the utmost exploitation 


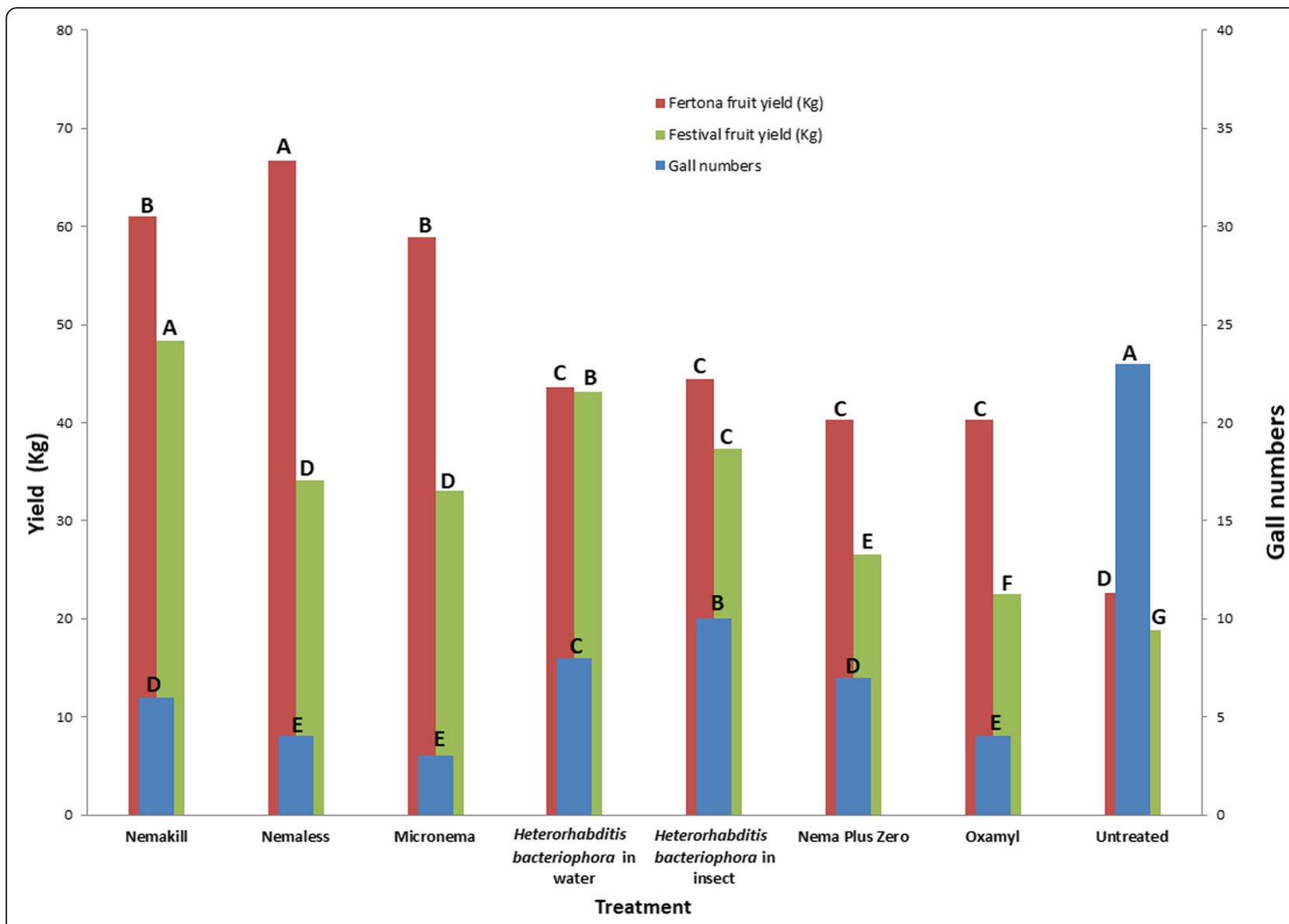

Fig. 3 Mean number of Meloidogyne incognita galls on two strawberry cultivars (Festival and Fortuna) treated with different nematicides to demonstrate their effects on the galls and fruit yield compared to untreated check. Means followed by the same letter on bars within a category did not differ significantly $(P \leq 0.05)$ according to Duncan's new multiple range test. Figure adapted from Tables 1, 3, and 4 in Hammam et al. (2019), based on data collected from two field experiments in Egypt

of the limited available fertile land and irrigating water. In addition, such a vertical expansion system may reduce PPN pressures by reducing their spread and reproduction if appropriate combinations of strawberry and non-host plants are utilized. In this vein, many growers tend to intercrop garlic with strawberry. They grow one or two rows of garlic plants per one-meter width bed which usually has four strawberry rows. Both oil (El-Habashy 2010) and aqueous extract (Tibugari et al. 2012) of garlic caused significant decrease in number of RKN galls and egg masses on roots and $\mathrm{J}_{2}$ number/ $250 \mathrm{~g}$ soil as well as improved root and shoot growth of strawberry cv. Festival compared with the untreated control (El-Habashy 2010). Also, the influence of legumes on the soil properties in the intercrop with strawberries was studied (Dane et al. 2017). So, broad bean (Vicia faba), pea (Pissum sativum), and clover (Trifolium hybridum) were intercropped with strawberries. Two control treatments were included in the trial: with and without nitrogen fertilizer usage where strawberries were planted in the field for 3 years. Results showed that there were significant differences between treatments in soil respiration rate (SRR) and SRR dynamic throughout the experiment time. The intercropping showed that legumes have a significant impact on the biological but not biochemical soil properties (Dane et al. 2017). Meanwhile, technical assessment of nematode-plant interaction should be adequately addressed (Abd-Elgawad 2016b).

Meloidogyne spp. have been frequent targets of management by crop rotation in Egypt and worldwide. Since strawberry is transplanted in Egypt as a winter crop in September and October, it is usually rotated with traditional summer crops such as cotton (Gossypium hirsuture), soybean (Glycine max), maize (Zea mays), or peanut (Arachis hypogaea). Such summer crops have been useful in rotation sequences for suppressing certain species and races of RKNs (e.g., McSorley and Gallaher 1991; Rodriguez-Kabana et al. 1991; Chen and Tsay 2006; Abd-Elgawad and Askary 2015). Chen and Tsay (2006) evaluated ten potential rotation crops and two 
cultural practices for their effect on nematode population levels of root-knot and lesion nematodes and influence on strawberry yield in 12 fields. They found that rotation with rice or taro and the cultural practice of flooding and bare fallowing for 4 months could reduce nematode soil populations to two or fewer nematodes per $100 \mathrm{~cm}^{3}$ soil. Average strawberry yields increased between 2.4 to $6.3 \%$ following taro compared to the bare fallow treatment. Also, corn could suppress RKN populations and resulted in an increase in strawberry yield compared to bare fallow. Based on economic analysis, they concluded that corn and bare fallow were the most appropriate rotation strategies for nematode management in strawberry in Dahu region of Taiwan. On the other hand, suppression of PPNs is particularly challenging on Egyptian strawberry where short crop sequences are frequently followed as strawberry last in soil from September to October till May. Eventually, caution should be exercised especially when such sequential crops are susceptible hosts or if infestations of multiple nematode species are found (Westphal 2011). On the other hand, observations indicate that fallowing for short durations coupled with early crop destruction and plowing can result in considerable and immediate reduction in total soil-borne pathogens, weeds, and nematode population densities in soil. Therefore, many Egyptian farmers follow this technique via summer fallow for 1-2 months during hottest months. Since soil type and soil organic matter content can also dramatically affect PPN population levels, the use of soil amendments might prove useful for control (Abd-Elgawad and Askary 2015; Noling 2016).

Plasticulture technologies proved effective against PPNs in Egypt. Reduction in number of RKN galls, egg masses, females/root system, and number of $\mathrm{J}_{2} / 250 \mathrm{~g}$ soil was attained with enhanced strawberry fruit quality and quantity (Mahdy and Midan 2011). Five different colored polyethylene sheets (transparent, red, black, green, and blue) were used to cover the naturally infested soil as a solarization and post-planting mulch. The highest reduction percentage of total nematode population and reproduction rates of RKN occurred in transparent sheet compared with the others (Bakr et al. 2013).

\section{Cover cropping}

Adequate use of cover cropping prior to strawberry transplanting can improve soil structure, suppress weeds, and if the proper cover crop is grown, suppress nematode populations. Recent research has shown that certain cover crops can kill disease organisms as well (Pritts and Nonnecke 2004). Benefits of a cover crop are greatest when the soil is sandy and/or the soil organic matter content is low. Although cover cropping prior to strawberry transplanting is not widespread in Egypt, many strawberry areas have such soil characteristics. Furthermore, to optimize this practice, the chosen cover crop should be compatible with time of year when a cover crop is desired, the crop to follow, $\mathrm{pH}$ and soil fertility, available tillage equipment, length of time the crop will be allowed to grow, and primary purpose of the cover crop (increasing soil organic matter, reducing weed populations, or controlling certain pests such as targeting a definite nematode species). Cover crops such as marigold, switch grass, and sunn hemp have been shown to reduce populations of root-knot (Osman et al. 2008), lesion (Pritts and Nonnecke 2004), and sting (Noling 2016) nematodes, respectively.

\section{Plant resistance/tolerance}

Cultivars with polygenic resistance to $M$. hapla have been bred in Europe, and varieties differ in their tolerances to the nematode (Warner 2018). Also, biochemical studies on isolation and characterization of RKN resistant genes to produce transgenic strawberry plants by molecular bio-techniques were done in Egypt (Salem 2016) as mentioned above. However, such information and results on resistance to M. hapla in Europe (Warner 2018) and transgenic strawberry plants resistant to $M$. incognita in Egypt (Salem 2016) are not readily available. Also, based on preliminary observation, some expression of sting nematode-tolerance in the cultivar "Sanibel" has been observed in the field in which strawberry plants grow and produce fruit but appear to be damaged less than susceptible varieties (Noling 2016).

\section{Conclusions}

Nematode sampling should be a pre-consideration. To properly detect and diagnose nematode problems, collection of adequate numbers of soil and/or plant tissue (roots and leaves) samples is necessary. Sampling reliability not less than $90 \%$ is adopted herein due to recent developments in sample collection, processing, and counting. Improving optimum size of nematode samples via iteration is also presented. No one nematode management strategy or tactic, with the exception of illegal $\mathrm{MB}$ soil fumigation, will effectively control all PPNs on strawberry. Therefore, adoption of integrated procedures for nematode control boosted by plasticulture technologies, multi-irrigation system, fertilization, and improved strawberry cultivars usually growing in 3-4 rows on bedded soil should be exercised. On the other hand, the need to back nematode quarantine and certification programs is apparent. Growers should use only the best quality transplants available and should if possible make special effort to inspect sources of strawberry transplants prior to planting in the field. Adequate cultural practices such as solarization, plastic mulching, 
intercropping, crop rotation, flooding, cover cropping, and/or plant resistance/tolerance should be selected in integrated pest management programs. Such programs may better include BCAs (Eissa and Abd-Elgawad 2015) in trends that make them able to contribute synergistically or complimentary to other chemicals/nematicides or BCAs.

\section{Acknowledgements}

This study was supported in part by the US-Egypt Project cycle 17 (no. 172 STDF) entitled 'Preparing and evaluating IPM tactics for increasing strawberry and citrus production'

\section{Funding}

Financial support made by US-Egypt Project fund for Project cycle 17 (no. 172) and National Research Centre, Egypt, is gratefully acknowledged.

\section{Availability of data and materials}

The datasets used and/or analyzed during the current study are available from the corresponding author on reasonable request.

\section{Authors' contributions}

The author wrote, read, and approved the final manuscript.

\section{Ethics approval and consent to participate}

Not applicable.

\section{Consent for publication}

Not applicable.

\section{Competing interests}

The author declares that he has no competing interests.

\section{Publisher's Note}

Springer Nature remains neutral with regard to jurisdictional claims in published maps and institutional affiliations.

Received: 10 December 2018 Accepted: 8 January 2019

Published online: 21 January 2019

\section{References}

Abd-Elgawad MM (1992) Spatial distribution of the phytonematode community in Egyptian citrus groves. Revue Nematol 14:367-373

Abd-Elgawad MMM (2008) The current status of phytonematode management in Egypt with special reference to applicable nematicides. Egypt J Agron 6:33-46

Abd-Elgawad MMM (2014) Yield losses by phytonematodes: challenges and opportunities with special reference to Egypt. Egypt J Agron 13(1):75-94

Abd-Elgawad MMM (2016a) Use of Taylor's power law parameters in nematode sampling. Int J PharmTech Res 9(12):999-1004

Abd-Elgawad MMM (2016b) Comments on the use of biocontrol agents against plant-parasitic nematodes. Int J PharmTech Res 9(12):352-359

Abd-Elgawad MMM, Abd El-Wahab AE, Koura FFH, Hammam MMA, Haroon SA (2008) Application of Taylor's power law to sample statistics of nematodes associated with cucurbits in Egypt. Egypt J Agron 6(2):159-170

Abd-Elgawad MMM, Askary TH (2015) Impact of phytonematodes on agriculture economy. In: Askary TH, Martinelli PRP (eds) Biocontrol agents of phytonematodes. CAB International, Wallingford, pp 3-49

Abd-Elgawad MMM, Hasabo SA (1995) Spatial distribution of the phytonematode community in Egyptian berseem clover fields. Fundam Appl Nematol 18: 329-334

Abd-Elgawad MMM, Koura FFH, Montasser SA, Hammam MMA (2016) Distribution and losses of Tylenchulus semipenetrans in citrus orchards on reclaimed land in Egypt. Nematology 18:1141-1150

Abdet-Sattar MA, El-Marzoky HA, Mohamed Al (2008) Occurrence of soilborne diseases and root knot nematodes in strawberry plants grown on compacted rice straw bales compared with naturally infested soils. J PI Prot Res 48(2):223-235
Amin WA (2001) First record of Aphelenchoides besseyi Christie 1942 (Nematoda: Aphelenchoididae) in Egypt causing white tip leaf disease on rice. Opusc Zool Bodapest 33:3-6

Anonymous (2018a) Strawberry. https://en.wikipedia.org/wiki/Strawberry. Accessed 7 Dec 2018

Anonymous (2018b) Aphelenchoides ritzemabosi. https://en.wikipedia.org/wiki/ Aphelenchoides_ritzemabosi. Accessed 7 Dec 2018

Anonymous (2018c) Nematodes in Strawberry and Raspberry Production. https:// www2.gnb.ca/content/gnb/en/departments/10/agriculture/content/crops/ small_fruits/nematodes.html. Accessed 4 Dec 2018

Bakr RA, Mahdy ME, Mousa EM (2011) A survey of root-knot and citrus nematodes in some new reclaimed lands in Egypt. Pak J Nematol 29(2):165170

Bakr RA, Mahdy ME, Mousa EM (2013) Efficacy of soil solarization and postplanting mulch on control of root-knot nematodes. Pak J Nematol 31(1):7176

Been TH, Schomaker CH (2013) Distribution patterns and sampling. In: Perry RN, Moens M (eds) Plant nematology, 2nd edn. CABI Publishing, Wallingford, pp $331-358$

CABI (2018) Invasive Species Compendium. https://www.cabi.org/isc/datasheet/ 6381. Accessed 7 Dec 2018

Chen P, Tsay TT (2006) Effect of crop rotation on Meloidogyne spp. and Pratylenchus spp. populations in strawberry fields in Taiwan. J Nematol 38(3): 339-344

Dane S, Laugale V, Lepse L, Silina D (2017) Influence of legumes on soil fertility in strawberry -legume intercropping. Res Rural Develop. https://doi.org/10. 22616/rrd.23.2017.045

DeMarree AM, Rieckenberg R (1998) Strawberry profit spreadsheet template. In: Pritts M, Handley D (eds) Strawberry production guide. NE Reg Agr Eng Serv. NRAES, Ithaca, p 88

Duncan LW, Phillips MS (2009) Sampling root-knot nematodes. In: Perry RN, Moens M, Starr JL (eds) Root-knot nematodes. CAB International, St. Albans, pp 275-300

Eisenback JD, Triantaphyllou HH (1991) Root-knot nematodes: Meloidogyne species and races. In: Nickle WR (ed) Manual of agricultural nematology. Marcel Dekker, New York, pp 281-286

Eissa MFM, Abd-Elgawad MMM (2015) Nematophagous bacteria as biocontrol agents of phytonematodes. In: Askary TH, Martinelli PRP (eds) Biocontrol agents of phytonematodes. CAB International, Wallingford, pp 217-243

El-Habashy DEMF (2010) Pathological studies on parasitic nematodes affecting strawberry, M. Sc. Thesis. Fac Agric, Damanhour, Alexandria Univ, Egypt

El-Shemy AA, Khafagy YS, Al-Genteery AMM (2013) Cultivation and production of strawberry. Techn issue no. 9/2013, General Directorate of Agricultural Culture, Egyptian Ministry of agriculture, Giza, 135 p. (in Arabic)

Essa TAA (2015) Response of some commercial strawberry cultivars to infection by wilt diseases in Egypt and their control with fungicides. Egypt $J$ Phytopathol 43(1-2):113-127

Hammam MMA, El-Nagdi WMA, Abd-El-Khair H, Abd-Elgawad MMM (2019) Biological management of the root-knot nematode on strawberry in Egypt. Egypt J Agron 18(1) In Press

Holladay BH, Willett DS, Stelinski LL (2016) High throughput nematode counting with automated image processing. BioControl 61:177-183

Ibrahim IKA (1985) The status of root-knot nematodes in the Middle East, Region VII of the International Meloidogyne Project. In: Sasser JN, Carter CC (eds) Advanced Treatise on Meloidogyne, Vol I, Biology and Control. North Carolina State Univ. Graphics, Raleigh, p 111

Ibrahim IKA (2006) Diseases and pests of fruit trees and control methods. Munsha'at Almaearif, Galal Hazzi \& Partners Company, Alexandria, p 319 (in Arabic)

Ibrahim IKA, Mokbel AA, Handoo ZA (2010) Current status of phytoparasitic nematodes and their host plants in Egypt. Nematropica 40:239-262

Inserra RN, Stanley JD, O'Bannon JH, Esser RP (2005) Nematode quarantine and certification programmes implemented in Florida. Nematol Mediterr 33:113-123

Jenkins WR, Taylor DP (1967) Plant nematology. Reinhold Publishing Corp, New York

Joseph SV, Martin T, Steinmann K, Kosina P (2017) Outlook of pyrethroid insecticides for pest management in the Salinas Valley of California. J Integ Pest Manag 8(1):1-11. https://doi.org/10.1093/jipm/pmx001

Korayem AM, Youssef MMA, Mohamed MMM, Lashein AMS (2014) A survey of plant parasitic nematodes associated with different plants in North Sinai. Mid East J Agric Res 3(3):522-529

Kuhar TP, Pfeiffer DG (2000) Insect Pests of Strawberries and Their Management. http://www.ento.vt.edu/Fruitfiles/StrawMaster.html. Accessed 5 Dec 2018 
LaMondia JA (1999) The effects of Pratylenchus penetrans and Rhizoctonia Fragariae on vigor and yield of strawberry. J Nematol 31:418-423

LaMondia JA, Cowles RS (2005a) Comparison of Pratylenchus penetrans infection and Maladera castanea feeding on strawberry root rot. J Nematol 37(2):131135

LaMondia JA, Cowles RS (2005b) Prevalence and potential impact of soil dwelling pests and insect pathogenic nematodes in strawberry fields. HortScience 40(5):1366-1370

Mahdy ME, Midan SA (2011) Physiological response of strawberry grown in rootknot nematode infested soil under different safety control applications. Arab Univ J Agric Sci 19:217-231

McSorley R, Gallaher RN (1991) Nematode population changes and forage yields of six corn and sorghum cultivars. Suppl J Nematol 23:673-677

Moens M, Perry RN, Starr JL (2009) Meloidogyne species: a diverse group of novel and important plant parasites. In: Perry RN, Moens M, Starr JL (eds) Root-knot nematodes. CABI Publishing, Wallingford, pp 1-17

Montasser SA, Sweelam ME, El-Mesalamy AF (2008) Ocurrence and distribution of Aphelenchoides arachidis on groundnut pods in Egypt - a new record. Pak J Nematol 26:151-152

Noling JW (2016) Nematode management in strawberries, University of Florida publication Series no. ENY-031, USA, p 12

Osman HA, El-Gindi AY, Taha HS, El-Kazzaz AA, Youssef MMA, Ameen HH, Lashein AM (2008) Biological control of root-knot nematode Meloidogyne incognita. 2-Evaluation of the nematicidal effects of Tagetes erecta tissue-culture under laboratory and greenhouse conditions. Egypt J Phytopathol 36:33-44

Oteifa BA, Elgindi DM (1983) Relative susceptibility of certain commercially important cultivars to existing biotypes of Meloidogyne incognita and $M$. javanica in Nile-delta Egypt. In: Proc. of the third Res. Plann. Conf. on Rootknot nematodes Meloidogyne spp., Region VII, Sept. 1982, Coimbra, Portugal

Pritts M, Nonnecke G (2004) Preplant cover crops for strawberries. Cornell Univ., Dept. of Hort., Ithaca http://www.fruit.cornell.edu/berry/production/pdfs/ strcovercrops.pdf. Accessed 1 April 2018

Qiu J, Westerdahl BB, Buchner RP, Anderson CA (1994) Refinement of hot water treatment for management of Aphelenchoides fragariae in strawberry. Suppl J Nematol 25:795-799

Reid A, Evans F, Mulholland V, Cole Y, Pickup J (2015) High-throughput diagnosis of potato cyst nematodes in soil samples. In: Lacomme C (ed) Plant Pathology: Techniques and Protocols, Methods in Molecular Biology, 2nd edn. Springer Science+Business Media, New York, pp 137-148

Rodriguez-Kabana R, Robertson DG, Wells L, Weaver CF, King PS (1991) Cotton as a rotation crop for the management of Meloidogyne arenaria and Sclerotium rolfsii in peanut. Suppl I Nematol 23:652-657

Salama HS, Abd-Elgawad MMM (2003) Quarantine problems: an analytical approach with special reference to palm weevils and phytonematodes. Arch Phytopath PI Prot 36:41-46

Salem AMA (2016) Biochemical studies on isolation and characterization of nematode resistant genes to produce transgenic plants by molecular biology techniques, Ph. D. Thesis. Fac Agric, Cairo Univ, Egypt

Samaliev HY, Mohamedova M (2011) Plant-parasitic nematodes associated with strawberry (Fragaria aiianassa duch.) in Bulgaria. Bulgarian J Agric Sci 17(6): $730-735$

Sturhan D (1962) Fber neue Wirtspflanzen der BlattSlchen Aphelenchoides fragariae und A. ritzemabosi, mit Bemerkungen zu den Wirtspflanzenkreisen beider Nematodenarten. Anz SchSdlingskunde 35(5):65-67

Tacconi R (1972) Infestations of Aphelenchoides fragariae, Aphelenchoides ritzemabosi and Ditylenchus dipsaci on strawberry in some Italian provinces. Redia 53:313-319

Tibugari H, Mombeshora D, Mandumbu R, Karavina C, Parwada C (2012) A comparison of the effectiveness of the aqueous extracts of garlic, castor beans and marigold in the biocontrol of root-knot nematode in tomato. $J$ Agric Tech 8(2):479-492

Van den Berg W, Hartsema O, Den Nijs LMF (2014) Statistical analysis of nematode counts from interlaboratory proficiency tests. Nematology 16:229243

Warner F (2018) Nematode Problems on Strawberries. https://pestid.msu.edu/ nematodes-problems-on-strawberries/. Accessed 7 Dec 2018

Westphal A (2011) Sustainable approaches to the management of plant-parasitic nematodes and disease complexes. J Nematol 43(2):122-125

Youssef MMA (2014) The leaf and bud nematode, Aphelenchoides besseyi, its identification, economic importance and control measures: a review. Mid East J Agric Res 3(3):46-464

\section{Submit your manuscript to a SpringerOpen ${ }^{\circ}$ journal and benefit from:}

- Convenient online submission

- Rigorous peer review

- Open access: articles freely available online

High visibility within the field

- Retaining the copyright to your article

Submit your next manuscript at $\boldsymbol{\nabla}$ springeropen.com 